\title{
Uzroci protestantske reformacije
}

\author{
GRGO GRBEŠIĆ* \\ - https://doi.org/10.31823/d.28.1.3 • \\ UDK: 274 Luther, M. • Pregledni članak \\ Primljeno: 14. listopada 2019. • Prihvaćeno: 11. veljače 2020.
}

Sažetak: Uzroci protestantske reformacije podijeljeni su u pet skupina: povijesni, teološki, duhovno-religiozni, politički, socijalni i psihološki i teologija Martina Luthera. Do dvadesetoga stoljeća provlačila se tradicionalna teza da glavni uzrok reformacije trebamo tražiti u brojnim zloupotrebama u Crkvi. Danas $i$ katolickki i protestantski autori promatraju problem mnogo sire i dublje te zahvaćaju teološku misao, osobito nominalizam koji je bitno utjecao na samoga Luthera. U spletu različitih okolnosti - političkih, socijalnih, psiholoških - dominirala je i Lutherova osobnost. Kao profesor biblijskih predmeta osobito se bavio proučavanjem poslanica Rimljanima $i$ Galaćanima. Pitanje oprosta pokrenulo je veliku lavinu koja se nije dala zaustaviti. Oprosti su samo povod, ali ne i uzrok protestantskoj reformaciji.

Grgo Grbešić, Katolički bogoslovni fakultet u Đakovu Sveučilišta J.J. Strossmayera u Osijeku, Preradovićeva 17, 31400 Đakovo, Hrvatska, grgo.grbesic@gmail.com

Ključne riječi: Martin Luther, reformacija, opravdanje, istočni grijeh, slobodna volja, skolastika, nominalizam, humanizam.

\section{Uvod}

Od 16. do 20. stoljeća među povjesničarima, bilo katoličkim bilo protestantskim, prevladala je teza da je korumpirano kršćanstvo glavni uzrok protestantske reformacije. Cilj ovoga istraživanja bio je prikazati prave uzroke koji su doveli do reformacije. Uzroci su podijeljeni u pet skupina. To su: povijesni, teološki, duhovno-religiozni, politički, socijalni i psihološki uzroci i teologija Martina Luthera.

Svaki od ovih uzroka ostavili su svoje tragove. Najdublji trag je ostavila teologija Martina Luthera i njegovo isku- 
stvo doživljaja u tornju. Njegov nauk o istočnom grijehu, o slobodnoj volji, o sakramentima i o opravdanju nije bio katolički. Upravo zbog tih teoloških razlika nije se moglo ponovno uspostaviti jedinstvo ni prije, ni za vrijeme niti poslije Tridentskog sabora.

\section{Povijesni uzroci}

\subsection{Tradicionalna TEZA}

I katolici kao i protestanti ponavljali su od 16 . do početka 20. stoljeća da su glavni uzroci koji su doveli do reformacije brojne zloupotrebe u Crkvi. U zloupotrebama je osobito prednjačila Rimska kurija. Papa Hadrijan VI. (1522. - 1523.) upro je prstom u Rimsku kuriju iz koje je proizišlo zlo koje se zove reformacija. Kao što se iz nje vjerojatno proširila korupcija na cijelu Crkvu, tako bi iz nje trebalo započeti ozdravljenje i reforma. Tu tezu ponovio je i papa Pavao III. (1534. - 1549.), crkveni oci Tridentskoga sabora, francuski književnik, teolog i biskup Jacques-Bénigne Bossuet (1627. - 1704.) i engleski povjesničar Lord Acton (1834. - 1902.) ${ }^{1}$

Početkom 20. stoljeća tradicionalnu tezu po kojoj je reformacija započela zbog korupcije u samom vrhu Crkve izložio je ozbiljnoj kritici Pierre-Gilbert-Jean-Marie Imbart de la Tour (1860. - 1925.). Protestantski povjesničar Georg Anton Hugo von Below (1858. - 1927.) postavio je pitanje zašto se reformacija nije dogodila u Italiji, u kojoj se nalazi sam vrh Crkve. Sam Luther po njemu nije stasao u jednom korumpiranom samostanu. Valdeški teolog Giovanni Miegge (1900. - 1961.) postavio je pitanje kako bi jedna dekadentna, iznutra tako slaba Crkva mogla pokrenuti tako moćan i vitalan pokret kao što je protestantska reformacija. Najnovija historiografija stavlja naglasak na religiozne uzroke reformacije koji su kao kvasac proželi sav društveni, ekonomski, politički i kulturni život. ${ }^{2}$

Danas i protestanti i katolici odbacuju tradicionalnu tezu da je korumpirano kršćanstvo 16. stoljeća uzrok protestantskoj reformaciji. Sam je Luther u svom djelu Kršćanskom plemstvu njemačke nacije 1520. godine zapisao: »Ne pobijam ja nemoralnost i zloupotrebe. Bit je papinski nauk. ${ }^{3}$

\subsection{AVINJONSKO SUŽANJSTVO I VELIKI ZAPADNI RASKOL}

Papa Inocent III. (1198. - 1216.) doveo je papinstvo na vrhunac svjetske moći. Borbe oko carskoga nasljeđa u Njemačkoj dovele su carstvo u duboku krizu. Ino-

\footnotetext{
${ }^{1}$ Usp. G. MARTINA, La Chiesa nell'età della Riforma, Brescia, 1988., 37.

${ }^{2}$ Usp. V. VINAY, La riforma protestante, Brescia, 1982., 71.

${ }^{3}$ G. MARTINA, La Chiesa nell'età della Riforma, 38.
} 
cent III. u takvoj situaciji izgradio je ugled, na crkvenom i na političkom planu, kojem su se svi pokoravali. Zapadna Europa bila je sastavljena od mnogo naroda koje je ujedinjavala ista vjera i Papa kao glava i vođa. Savez između prijestolja i oltara (brachium saeculare) doživljava svoj vrhunac.

Iako je postojala velika bliskost između trona i oltara, ipak je u zapadnoj Crkvi bio prisutan dualizam. Pape su branili svoju neovisnost u odnosu na carsku vlast kako bi sačuvale svoj univerzalni karakter.

Francuski kralj Filip Lijepi (1285. - 1314.) nakon što ga je izopćio papa Bonifacije VIII. (1294. - 1303.) dao je Papu zarobiti u njegovu dvorcu u Anagniju. Papa je nakon nekoliko tjedana umro, a s njim i univerzalna papinska prevlast u srednjem vijeku.

Papa Klement V. (1305. - 1314.) izabrao je francuski grad Avignon kao svoje sjedište. Razdoblje avinjonskoga sužanjstva trajalo je od 1305. do 1377. godine. Koliki je bio utjecaj francuskih kraljeva pokazuje nam sudski postupak protiv pokojnoga pape Bonifacija VIII. te dokinuće križarskoga reda templara na saboru u Vienni 1312. godine. Glavni razlog dokinuća reda nije bilo krivovjerje, nego njihova imovina koje se dočepao francuski kralj Filip Lijepi.

Avinjonsko sužanjstvo završilo je povratkom u Rim pape Grgura XI. (1370. - 1378.) Velike zasluge za Papin povratak pripadaju sv. Katarini Sijenskoj i Brigiti Švedskoj. Od nekadašnjega rimskoga sjaja nije ostalo više ništa. Papa se razočaran htio vratiti u Avignon, ali ga je u tome spriječila smrt.

Izbor novoga pape bio je buran i pod velikim pritiskom naoružane mase koja je prodrla u palaču tražeći da novi papa bude Rimljanin. Kardinali u strahu za svoj život izabrali su nadbiskupa Barija koji je uzeo ime Urban VI.

Tri mjeseca poslije izbora Urbana VI. francuski kardinali (njih 11) i jedan Španjolac izabiru novoga papu koji je uzeo ime Klement VII. i vratio se u Avignon. Prijepor oko toga koji je papa valjano izabran ostao je među povjesničarima do danas. $\mathrm{Ne}$ može se reći da je izbor Urbana VI. potpuno valjan jer je bila riječ o prijetnji i pritisku niti da je izbor Klementa VII. potpuno nevaljan.

Veliki zapadni raskol (1378. - 1414.) donio je Crkvi velike nerede i bolne podjele. Pariško sveučilište 1394. godine ponudilo je tri načina da se riječi raskol:

1. Via cessionis (dobrovoljno odreknuće)

2. Via compromissi (podvrgavanje papa izbornom sudu)

3. Via concilii (odluku će donijeti opći sabor). ${ }^{4}$

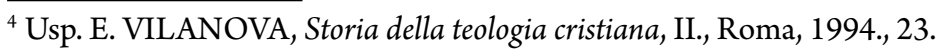


Kardinali i rimske i avinjonske obedijencije sazvali su u Pisi 1409. godine opći sabor. Sabor je svrgnuo obojicu papa i izabrao novoga papu koji je uzeo ime Aleksandar VI. Njega je nakon godinu dana naslijedio Ivan XXIII.

Ni rimski papa Grgur XII. ni avinjonski Benedikt XIII. nisu se htjeli povući tako da su se umjesto dvojice papa na čelu Crkve nalazila trojica. Tu bolnu podjelu riješit će sabor u Konstanci (1414. - 1418.) koji će na čelu s njemačkim kraljem Sigismundom razriješiti svu trojicu papa i izabrati 1417. godine papu Martina V.

Posljednja šizma u povijesti Crkve dogodit će se izborom Feliksa V. na saboru u Baselu-Ferrari-Firenci (1431. - 1435.).

Jedna od posljedica zapadne šizme jest tendencija stvaranja nacionalnih crkava. Tako je u Francuskoj 1438. godine objavljena Pragmatička sankcija. Da bi dobila na svojoj vjerodostojnosti, pripisali su je svetom francuskom kralju Luju IX. (1226. - 1270.) Pragmatička sankcija potvrdila je kao državne zakone mnoge dekrete sabora u Bazelu. Tako npr. potvrdila je koncilijarističku teoriju, zabranu priziva na Rim kao posljednju instanciju, ograničavanja prava Svete stolice u imenovanjima za nadarbine u Francuskoj.

U Njemačkoj su se pritužbe na Rim najbolje očitovale u Gravamina Nationis Germanicae. Knezovi su počeli uzurpirati crkvenu jurisdikciju na svome teritoriju tako što su imenovali crkvene službenike, što su tražili nihil obstat od države za dekrete Svete stolice i što su nametali takse na crkvena dobra.

U Engleskoj se nepovjerenje prema Rimu razvilo za vrijeme avinjonskoga sužanjstva, kada je Papa promatran kao instrument francuskoga kralja. U Španjolskoj čuvena španjolska inkvizicija nije bila pod kontrolom Crkve, nego pod kontrolom države. ${ }^{5}$

\subsection{KonCILIJARIZAM}

$\gg$ Koncilijarizam se naziva jedna od brojnih teorija kanonista koje su izgrađene $\mathrm{u}$ 12. i 13. st. i prema kojoj ekumenski sabor ima prvenstvo nad papom. $\ll^{6}$ Koncilijaristička teorija vraća nas u 11. stoljeće kada je Umberto di Silva Candida dao definitivan oblik tezi iz VII. stoljeća da papa heretik može biti podvrgnut sudu i smijenjen na Saboru. Taj ekstremni korak primjenjivao bi se u slučaju da treba spasiti Crkvu. Nije se činilo da je teza u suprotnosti s papinim primatom.

Tu delikatnu ravnotežu poremetila su učenja Ivana Pariškoga (1255. - 1306.) u djelu De potestate regia et papali, djelo Defensor pacis Marsilija iz Padove (oko 1275.

\footnotetext{
${ }_{5}^{5}$ Usp. G. MARTINA, La Chiesa nell'età della Riforma, 58-60.

${ }^{6}$ K. RAHNER, H. VORGIMLER, Teološki rječnik, Đakovo, 1992., 247.
} 
- oko 1342.) i Dialogus de imperatorum et pontificum potestate Williama Ockhama (oko 1287. - oko 1347.). Oni su papu sveli na izvršitelja saborskih odredbi. Subjekt autoriteta nije samo glava nego glava i udovi. Car je taj koji saziva sabor na kojem mogu sudjelovati i laici. ${ }^{7}$

M. Padovanski u svom djelu Defensor pacis išao je za potpunim ukidanjem crkvene vlasti i potpunim vladanjem države na svim područjima života i nad Crkvom. Marsilije vidi temeljno zlo u papinu polaganju prava na puninu vlasti. Crkvena je vlast delegirana. Biskupi i svećenici primili su vlast od ljudskoga zakonodavca, vjernika, tj. laika. Po njemu nisu samo biskupi, svećenici i đakoni Crkva, nego svi koji u Krista vjeruju. Hijerarhija nije božanskoga, nego ljudskoga prava. U teološkim sporovima odluku bi trebao donijeti sabor. Istinito je Sveto pismo i tumačenje koje je dao opći sabor. Ljudski zakonodavac, vjernik ili onaj koji vlada po njegovoj punomoći može sazvati neki sabor, izabrati i odrediti pogodne osobe te naložiti obdržavanje saborskih zaključaka. Niti papa upravlja Crkvom na monarhistički način, niti kolegijalno episkopat, niti demokratski koncil.

Godine 1327. iz Defensor pacis osuđeno je pet teza kao krivovjerno:

1. >Krist je plaćanjem poreznog novčića htio posvjedočiti svoju podložnost svjetovnoj vlasti.

2. Petar nema više autoriteta nego ostali apostoli.

3. Car može papu postaviti, skinuti i kazniti.

4. Svi su svećenici istoga ranga.

5. Svećenici nemaju nikakve kaznene vlasti sami od sebe, nego po carevoj delegaciji. $\ll^{8}$

Defensor pacis bio je preradikalan da bi bio neposredno prihvaćen, ali je posredno imao velik utjecaj.

\subsection{RENESANSNI PAPE}

Renesansu možemo definirati kao razdoblje u europskoj kulturi 15. i 16. stoljeća koje karakterizira obnavljanje antičke kulture, afirmacija individualizma i svestranoga, intelektualnoga, radoznaloga čovjeka. Jacob Burckhardt smatra da je renesansa učinila zaokret u europskoj civilizaciji koja će se temeljiti na ovozemaljskom i laičkom poimanju svijeta. Renesansa se nadovezuje na humanizam kao kulturni pokret kasnoga srednjega vijeka. Nastala je u Italiji, i to u urbanim središtima sjever-

${ }^{7}$ Usp. E. VILANOVA, Storia della teologia cristiana, 23.

${ }^{8}$ E. ISERLOH, Nominalizam. Pojam Crkve i ideja države u polemici 14. stoljeća. Laicistička država u Marsilija Padovanskog, u: H. JEDIN (ur.), Velika povijest crkve, III, Zagreb, 1993., 418. 
ne i srednje Italije, najprije u Firenci, potom Sieni, Lucci, Ferrari, Mantovi, Urbinu, Milanu, Rimu. ${ }^{9}$

Na nastanak renesanse utjecale su i ekonomske i intelektualne razmjene Europe i arapskoga svijeta koje su bile posljedica križarskih ratova i španjolske rekonkviste, propast Bizanta, nakon koje su mnogobrojni grčki učenjaci došli u Italiju.

Renesansa je reakcija na dvije tendencije. Jedna je bijeg od svijeta, a druga je podvrgavanje svega vjeri. Ona je je stavila naglasak na autonomiju ljudske aktivnosti. Literarni aspekt renesanse nazivamo humanizam.

Renesansni pape nastavili su tradiciju staroga i srednjega vijeka da skupljaju i krste sve tendencije ljudskoga duha koje u sebi nisu zle. Vrh Crkve u vrijeme renesanse postao je vodeći u promicanju umjetnosti, a zanemario reformatio in capite et in membris. Autentičan religiozni život zamijenjen je kulturnim sjajem. U renesansi je poremećena ravnoteža između vjerskih dužnosti i mecenatstva.

Pape su htjeli od Rima načiniti dostojno sjedište Kristova vikara. Nikola V. (1447. 1455.) utemeljio je Vatikansku biblioteku i okupio oko sebe brojne humaniste. Siksto IV. (1471. - 1484.) dao je sagraditi Sikstinsku kapelu. Julije II. (1503. - 1513.) planirao je sebi podići veličanstven grob. Od te zamisli realiziran je samo Mojsijev kip. U Vatikanu djeluju brojni umjetnici među kojima posebno ističemo Michelangela i Rafaela. Svaki kardinal imao je svoje palače i vile u Rimu i izvan njega. U središtu kršćanskoga svijeta podignuta je nova bazilika sv. Petra. Od brojnih umjetničkih djela u bazilici spomenut ćemo samo Michelangelova Pietà. ${ }^{10}$

Rano kršćanstvo prihvatilo je grčko-rimsku kulturu u vremenu njezine transformacije pod utjecajem orijentalnoga misticizma. $U$ poeziji religiozne inspiracije u svečanom karakteru umjetnosti kasne antike, u filozofiji vidjela se evandeoska priprava. Platon i Vergilije promatrani su kao suradnici u naviještanju spasenja i Spasitelja.

Antička kultura ponovno je, drugi put, budila interes na zapadu. U klasičnoj kulturi otkriva se slobodnija umjetnost i optimističniji životni izraz. To cvjetanje u Europi dolazi poslije stogodišnjih različitih stradanja: epidemije, gladi, straha. Društvo u jednom demografskom i ekonomskom širenju otkrilo je svoj ideološki izraz u povratku na klasičnu kulturu.

Neki su pokušali spojiti kršćansku pobožnost s kultom ljepote i uzdizanja čovjeka. Botticelli približava Apolona i Krista. Tim tipom sinkretizma kršćanska se vjera ispražnjavala od svojih bitnih postavki.

\footnotetext{
${ }^{9}$ Usp. J. BURCHARDT, Kultura renesanse u Italiji, Zagreb, 1953.

${ }^{10}$ Usp. G. MARTINA, La Chiesa nell'età della Riforma, 61-73.
} 
J. Savonarola i M. Luther ustali su protiv $\gg$ idolatrijskih presizanja ove čovjekove religije $\ll .{ }^{11}$ Takva je reakcija ambivalentna. $S$ jedne strane doprinosi buđenju osjećaja vjere kod kršćana da ne budu zahvaćeni samo humanim vrijednostima, a s druge strane prijeti opasnost da se Crkva izolira od razvoja kulture, koju ona treba inspirirati i usmjeravati. Grčko-rimska kultura nosila je svoje poroke, ali i autentične estetske vrijednosti i živi osjećaj čovjekove odgovornosti koji su se mogli staviti u službu kršćanske vjere.

U konačnici to sučeljavanje između kršćanstva i humanizma jedna je borba za značenje čovjeka. Društvo je uvijek u napasti da se zablati u vlastita otkrića, sjajna, ali ograničena. Kršćanstvo prelazi tu granicu i dolazi do izvora svake ljepote i vrijednosti. Kršćanstvo naučava da je čovjek ranjen grijehom i da mora prihvatiti križ kao sredstvo ozdravljenja. Dalje naučava relativnost naravnih vrijednosti pred apsolutnim Bogom, jedinom svrhom ljudskoga života. U tom odnosu čovjeka s Bogom otkriva se svijet u svojoj ljepoti. Ćovjek uči ljubiti i postaje veći jer nalazi u uskrsnuću vlastite autentične dimenzije.

Papa Nikola V. bio je prvi papa renesanse. On je okupljao na svome dvoru stotine učenjaka koji su prevodili grčke pisce na latinski. Vatikanska biblioteka može ga smatrati svojim utemeljiteljem. Kupovao je rukopise. Nikola V. prvi je iznio plan rušenja Konstantinove bazilike i gradnju nove. Papa Pio II. (1458. - 1464.) bio je jedan od najslavnijih humanista svojega vremena. On se zauzeo odmah nakon izbora u organizaciji križarske vojne protiv Turaka. Pozvao je u Mantovu kršćanske vladare radi zajedničke strategije u borbi protiv Turaka. Papa je doživio neuspjeh. $\mathrm{Na}$ novi poziv u Anconu 1463. godine odazvao se mali broj križara. Teško bolestan i razočaran, Papa umire u Anconi. Siksto IV. pretvorio je srednjovjekovni Rim u renesansni grad. Njegovo najpoznatije djelo jest Sikstinska kapela. Aleksandar VI. (1492. - 1503.) predstavlja najnižu točku papinstva. On je više bio svjetovni vođa nego poglavar Crkve. To se osobito očitovalo u spletkarenju i brizi za vlastitu djecu. Pomagao je svomu sinu Cesaru da u srednjoj Italiji osnuje vlastitu državu, a kći Lukrecija postala je sinonim ćudoredne pokvarenosti zbog ženidbene politike vlastitoga oca.

Julije II. jest $\gg$ bio čovjek sile stvaralačke energije i čelične volje, pravi vladar i vojskovođa, ali premalo papa i svećenik«. Od Leona X. (1513. - 1521.) nije se moglo ništa očekivati. Nakon izbora za papu izjavio je: »Naužijmo se papinstva, Bog nam ga je dao. $\ll^{12}$

${ }^{11}$ Il ritorno dell'umanesimo pagano u: E. BARATTE, P. BARBARIN i dr. (ur.), 100 punti caldi della storia della Chiesa, Roma, 1984., 200.

${ }^{12}$ J. KOLARIĆ, Ekumenska trilogija. Istočni kršćani - pravoslavni - protestanti, Zagreb, 2005., 425-428. 
Sablažnjiv život Rimske kurije i renesansnih papa, simonija i nepotizam ostavili su duboke tragove u Crkvi. Nezadovoljstvo je sve više raslo. Dominikanac Jeronim Savanorola (1452. - 1498.) glasno je prosvjedovao protiv Aleksandra VI., kojega nije smatrao pravim papom. Zbog toga je bio izopćen i spaljen na lomači. Bitno je reći da Savonarola nikada nije osporavao papinstvo. Taj korak učinit će Martin Luther dvadesetak godina poslije Savonaroline smrti.

\section{Teološki uzroci}

\subsection{Dekadencija Skolastike i nominalizam}

Skolastika je misaoni sustav koji se razvio u srednjem vijeku, a ima svoje korijene kod svetoga Augustina i Boetia. Petar Abelard (1079. - 1142.) dao je temeljni doprinos skolastičkoj metodologiji, a sveti Toma Akvinski (1225. - 1274.) na genijalan način povezao je objavu i razum i pokazao kako se oni nadopunjuju.

Već krajem 13. stoljeća skolastika je počela gubiti ugled, a u 16. stoljeću pred novim humanističkim duhom sve veći broj učenjaka do nje nije mnogo držao. Teološka skolastička misao bila je udaljena od realnosti. Erazmo Roterdamski u svome djelu Pohvala ludosti ismijao je teologe svoga vremena i njihove jalove rasprave. Njemu kao humanistu bio je dalek misaoni skolastički sustav. Ludost smatra teologe nevjerojatno svadljivim i razdražljivim jer na sve ostale smrtnike gledaju s visoka. Toliko su »obrazovani « da bi samim apostolima bio potreban još jedan Duh Sveti da bi mogli s njima »ukrstiti mačeve o ovim pitanjima «. Apostoli su krstili ljude posvuda, a nikada nisu poučavali koji je formalni, materijalni, finalni uzrok krštenja. Apostoli >osuđuju grijeh ali umrla ja ako su oni mogli znanstveno odrediti što je to što nazivamo grijehom $\ll$. To što Ludost primjećuje to je za teologe plitko teološko raspravljanje. Teolozi »tako podrobno opisuju sve što se događa u paklu, kao da su godinama stanovali u toj državi ${ }^{13}$

U središtu skolastičke misli nalazilo se univerzalno i objektivno. Početkom 14. stoljeća naglasak se u filozofiji i teologiji stavlja na individualno. Poseban doprinos u tome dao je William Ockham (oko 1285. - 1349.). On je protivno skolastičkoj misli tvrdio da univerzalije nemaju mjesta u realnosti. Primjenom aristotelovskih načela on je uzdrmao sintezu između filozofije i teologije koja je uspostavljena u skolastičkoj misli. ${ }^{14}$ Njegovo učenje dobilo je naziv nominalizam. Kada se govori o nominalizmu, onda se redovito misli na teoriju spoznaje, tj. na spor oko univerzalija, no on je ostavio osobit trag u teologiji. Polazna točka nominalizma jest razdvajanje misli od bitka.

\footnotetext{
${ }^{13}$ E. ROTERDAMSKI, Pohvala ludosti, Zagreb, 2009., 111.,113.,116.

${ }^{14}$ Usp. B. LOHSE, Martin Luther, Zagreb, 2006., 25.
} 
$\gg$ Odvajanje misli od bitka proizvelo je u teologiji sklonost da se na osnovi potentia dei absoluta (apsolutne Božje svemoći) istražuju sve mogućnosti koje bi se samo mogle zamisliti, te da se zanemari put spasenja koji je već stvarno dan u vrelima objave i obvezatan. Kada se napustio simbolički karakter riječi i pojma, tada više nije bilo mjesta za simbole. Time pak je zatvoren prilaz do dubljeg razumijevanja sakramenata. $\ll{ }^{15}$

W. Ockham prenaglasio je Božju svemoć. Bog u svojoj svemoći može osuditi i baciti u pakao pravednika i isto tako opravdati i posvetiti grješnika bez njegova nutarnjega obraćenja. Luther je nazvao Ockhama svojim dragim učiteljem.

Ockham je bio optužen pred Papom u Avignonu na pretjeranu spekulaciju de potentia dei absoluta (o apsolutnoj Božjoj moći) zbog nauka o euharistiji, akcepciji i milosti. Ockham je pobjegao prije osude iz Avignona i našao utočište kod Ljudevita Bavarskoga.

U nauku o Bogu Ockham naglašava Božju slobodu i svemoć. Bog može u sebi ostvariti sve što ne uključuje proturječje. On je slobodan i naspram poretka koji je stvorio. Mogao bi i zapovijedi dokinuti. Bog ne podliježe nikakvoj nuždi i zato nije vezan čovjekovim bićem i ponašanjem.

Što se tiče euharistije, Ockhamu bi se više svidjela koegzistencija kruha i tijela Kristova. Na taj način bi riješio najveću poteškoću, tj. opstojnost akcidenata. On ipak prihvaća transsupstancijaciju koju je Crkva prihvatila. Za Ockhama milost nije sila koja se daje čovjeku, nego je ona $\gg$ Božja naklonost kojom čovjeka prihvaća ili ne prihvaća, kako mu se svidi $\ll^{16}$. Car kao vjernik može sazvati sabor, pa i svrgnuti Papu, može upotrijebiti crkvena dobra za svjetovne svrhe. Ockham je naglašavao samostalnost svjetovne i duhovne vlasti. Crkva bi se trebala odreći svjetovnih pozicija. Nažalost, on nije uočio opasnost državnoga apsolutizma.

Sva teološka pitanja o kojima je Luther raspravljao već su, na ovaj ili onaj način, bila izložena u 14-om i 15-om stoljeću. Potrebno je spomenuti trojicu autora. To su John Wickliff (1320. - 1384.), Jean Hus (1369. - 1415.) i Giovanni Wessel (†1489.). Tako je J. Wickliff uzimao Pismo kao jedinu normu vjere, predodređeni su jedino članovi Crkve, a Crkva je bitno nevidljiva. Negirao je papin primat, transsupstancijaciju i slobodnu volju. Giovanni Wessel (- 1489.) odbio je nauk apostolske tradicije, oproste i papin autoritet. Prihvaćao je nevidljivu Crkvu bez vlasti i hijerarhijske strukture. ${ }^{17}$

${ }^{15}$ E. ISERLOH, Nominalizam. Sveučilišta između via antiqua i via moderna, u: H. JEDIN (ur.), Velika povijest crkve, III, Zagreb, 1993., 400.

${ }^{16}$ Isto, 405.

${ }^{17}$ Usp. G. MARTINA, La Chiesa nell'età della Riforma, 1988., 80-81. 


\subsection{TeOlošKa NeJASNOĆA}

U teologiji do Tridentskoga sabora (1545. - 1563.) nije postojao točan i iskristaliziran nauk o Crkvi, primatu, opravdanju, istočnom grijehu, slobodnoj volji. Nažalost, s velikim zakašnjenjem tek je Tridentski sabor donio jasnoću po tom pitanju.

Glavna točka spora između rimokatolika i protestantskih reformatora Martina Luthera (1483. - 1546.) i Jeana Calvina (1509. - 1564.) bio je nauk o opravdanju.

U borbi protiv Pelagija (354. - 422./440.), britanskoga asketa koji je prenaglasio ulogu ljudske naravi u pitanju spasenja, sveti Augustin kada je govorio o iskvarenosti ljudske naravi tvrdio je da je opravdanje moguće jedino po milosti. Toma Akvinski isto tako naglasio je prvenstvo milosti, ali je isto tako govorio i o načinima kojima su ljudska bića preobražena milošću. To se pitanje zaoštrilo pod utjecajem nominalizma. ${ }^{18} \mathrm{Za}$ razliku od Luthera Ockham je sačuvao važnost ljudske naravi u pitanju spasenja. Luther je obezvrijedio ljudsku narav koja nije sposobna činiti dobra djela i po kojoj se ne možemo opravdati.

\section{Duhovno-religiozni uzroci}

\subsection{LAŽNI MISTICIZAM}

U 14-om stoljeću u Njemačkoj se razvila mistična škola koja u određenim slučajevima nije sačuvala pravovjerje. Protivnici skolastike posvećivali su se kontemplaciji, studiju Svetoga pisma tražeći osobni odnos s Bogom. Među duhovnim učiteljima spomenut ćemo Johannesa Eckharta, poznatoga kao Meistera Eckharta (1260. - između 1327. i 1329.), Ivana Taulera (1300. - 1361.), Jana van Ruysbroecka (1293. - 1381.). Osim njih tu su i begine, begardi, braća slobodnoga duha.

Učenja Maistera Eckharta, ako su uzmu doslovno, mogu se tumačiti krivovjerno. Tako je on došao do točke da je negirao razliku duše i Boga u mističnom sjedinjenju i tako pao u panteizam. Isto tako negirajući dobra djela, približio se kvijetizmu. $\mathrm{Na}$ Luthera presudni utjecaj imao je Ivan Tauler. ${ }^{19}$

Crkva je trpjela čulno prikazivanje Božje ljubavi. Jean Charlier de Gerson (1363. - 1429.) tu je opominjao na oprez. Iz iskustva je znao da amor spiritualis facile labitur in nudum carnalem amorem ( $\gg$ Duhovna se ljubav lako izopaćuje u čistu putenu ljubav $\ll) .{ }^{20}$ Kao pobornik umjerene bernadinske mistike nije mogao dopustiti osjećaj potpunoga uništenja JA što su ga osjećali mistici vremena. Do toga osjećaja,

\footnotetext{
${ }^{18}$ Usp. T. TOBIN, Opravdanje, u: M. GLAZIER, M. HELLWIG (ur.), Suvremena katolička enciklopedija, Split, 1998., 684-685.

${ }^{19}$ Usp. G. MARTINA, La Chiesa nell'età della Riforma, 81-82.

${ }^{20} \mathrm{~J}$. HUIZINGA, Jesen srednjega vijeka, Zagreb, 1991., 184.
} 
da savršena duša ne može više griješiti, došli su i indijski i neki kršćanski mistici. Neka vizionarka rekla je Gersonu da $\mathrm{u}$ »gledanju Boga njezin duh biva pravim uništenjem uništen i potom iznova stvoren $\ll{ }^{21}$ Duša izgubljena u Bogu nema više vlastite volje, nego je samo preostalo božansko htijenje. Ako se i podliježe putenim sklonostima, $\mathrm{u}$ tome nema više grijeha. To je učenje mnoge siromašne i neuke duže odvelo na put razuzdanosti. Jedan je ugledni čovjek kazao da ga smrtni grijeh, to jest putena ljubav, ne sprječava u ljubavi prema Bogu, nego ga još više potiče da u njemu božanska slast još više raste.

Kvijetizam, duhovni pokret iz 17. stoljeća čiji je začetnik španjolski svećenik Miguel de Molinos (1628. - 1696.), koji je Crkva osudila, prethodno se pojavljivao u različitim oblicima bilo na zapadu bilo na istoku. Već u istočnoj Crkvi veliko, ali jednostrano valoriziranje kontemplacije božanskoga svjetla nosili su u sebi opasnosti slične kvijetizmu. Na zapadu se u srednjem vijeku nešto slično pojavilo kod Braće i sestara slobodnoga duha. Oni ne samo da su odbili temeljna kršćanska učenja nego i moralni zakon. U Španjolskoj su u 16. st. alumbradosi (»prosvjetljeni«) nosili kvijetističke naznake. Molinos je u Rimu vrjednovan kao veoma zelozan i pobožan duhovnik. On je tvrdio da se kršćansko savršenstvo sastoji u potpunom prepuštanju Bogu. To prepuštanje potpuno je pasivno. Osuđuje se osobno zauzimanje na moralnom planu. Riječ je o jednoj nerealnoj duhovnosti koja želi riješiti pitanje grijeha, slabosti, volje tako da se ne želi ništa i ne čini ništa, nego samo $\gg$ mirna molitva $\ll{ }^{22}$

Opasnost Molinova kvijetizma sastoji se od opasnosti radikalnoga subjektivizma. Pounutrašnjenje se predstavlja kao nešto pozitivno, a da se ne govori o rizicima i anarhiji. Vlastita volja može se zamjenjivati Božjom voljom.

\subsection{Evangelizam}

Humanistički princip ad fontes bio je usmjeren prema Bibliji, a ne prema dogmama i srednjovjekovnoj teologiji. Zbog toga su povjesničari i teolozi dugo vremena osuđivali humanizam, jer su smatrali da je on negirao kršćansku prošlost. Tek sredinom 20. stoljeća s obnovom biblijskoga i patrističkoga studija došlo se do novoga vrjednovanja kršćanskoga humanizma. Evangelist Vilanova, pozivajući se na brojne autore, tvrdi u svome djelu Storia della teologia cristiana da je teološka obnova koja se dogodila u 20. stoljeću zakašnjeli završetak onoga što su započeli kršćanski humanisti. ${ }^{23}$

Humanistički duh koji je pozivao na izvore osobito se osjećao u duhovnom pokretu devotio moderna. Taj pokret nastao je u Katoličkoj Crkvi 14. i 15. st. u Nizozemskoj.

\footnotetext{
${ }^{21}$ Isto, 185.

${ }^{22}$ J. LORTZ, Storia della Chiesa in prospetiva di storia delle idee, II, Milano, 1987., 309-312.

${ }^{23}$ Usp. E. VILANOVA, Storia della teologia cristiana, 48-49.
} 
Glavne karakteristike duhovnosti devotio moderne jesu kristocentričnost i biblizam. Devotio moderna stavila je Sveto pismo kao glavni izvor kršćanske duhovnosti. Ta nova pobožnost stavlja naglasak na nutarnji život čitanjem i meditiranjem Svetoga pisma i osobnom molitvom. Najistaknutiji predstavnik toga pokreta jest Toma Kempenac sa svojim djelom Nasljeduj Krista.

Erasmo Roterdamski (1469. - 1536.) spojio je devotio modernu, prožetu biblicizmom i antiskolastikom, s humanizmom firentinske škole koja je nastojala uskladiti kršćanstvo s Platonovom filozofijom. On u svojim djelima postavlja problem kršćanskoga humanizma. ${ }^{24}$

Erazmo nije bio duboki mislilac, a ni prorok. On je u određenom smislu postao tumač svoga vremena. Utjelovio je humanizam u kršćanstvo. U svojim spisima širio je ideju o toleranciji, pročišćenju zastarjelih struktura, o povratku na izvore. Erazmo je bio čisti intelektualac, a ne čovjek akcije, manje originalan i kreativan kako izgleda na prvi pogled.

Povjesničari s katoličkim predznakom držali su Erazma slabićem, i u fizičkom i u moralnom smislu, koji je prvo svojim sarkazmima, a zatim neodlučnošću dao poticaje za reformaciju. Erasmus posuit ova, Lutherus exclusit pullos (»Erazmo je snio jaja, a Luther je izlegao piliće «). Sadašnji povjesničari, iako dopuštaju njegove intelektualne i moralne granice, pokazuju više dobronamjernosti prema njemu. On je promatran kao preteča katoličke reforme u prvoj polovici 16. stoljeća. Oni su preoblikovali stari izraz na sljedeći način: Erasmus posuit ova, Loyola exclusit pullos (»Erazmo je snio jaja, a Loyola je izlegao piliće.«). ${ }^{25}$

Velik promicatelj Svetoga pisma u Francuskoj bio je Faber Stapulensis (oko 1455. - 1536.). Napisao je brojne komentare Svetoga pisma, priredio je prijevod Svetoga pisma na francuski jezik. Najvaznije mu je djelo Psalterium quintuplex. Za njega možemo reći da je začetnik evangelizma u Francuskoj.

Martin Luther preveo je Sveto pismo na njemački jezik. Bitno je reći da ga on nije otkrio, nego da je on upio već postojeći novi duh povratka na izvore kojem je dao vlastito obilježje.

\subsection{Svjetovan život u CRKVI}

Jedan od uzroka reformacije bio je i nemoralan život klera. U nemoralu su prednjačili loši pape. Aleksandru VI. pripisuju se mnoga sramotna djela. Drugima zastrašujuća nebriga, neodgovorna lakoumnost, hedonizam i potpuno svjetovan život.

\footnotetext{
${ }^{24}$ Usp. L. E. HALKIN, Erasmo i kršćanski humanizam, Zagreb, 2005., 91-97.

${ }^{25}$ E. VILANOVA, Storia della teologia cristiana, 66-69.
} 
$\gg$ Porok je postao toliko po sebi razumljiv da oni koji su njima okaljani ne osjećaju više smrad grijeha. $\ll^{26}$ Te riječi izrekao je nasljednik Leona X. Hadrijan VI. u svom prvom konzistorijalnom govoru.

Konkubinat svećenika bio je u pojedinim krajevima toliko raširen da se vjernici nisu baš ni sablažnjavali nad svojim dušobrižnicima.

$\gg$ Bez pretjerivanja može se reći da Crkva izgleda kao vlasništvo klera, vlasništvo koje donosi materijalnu dobit i udobnost (...) Biskupi i župnici (...) su se osjećali kao posjednici kakva imanja, nadarbine, u smislu germanskog feudalnog prava. Te su nadarbine uključivale pravo uporabe, povezano s određenim službenim dužnostima. Dužnosti su se međutim mogle prenijeti na kakva loše plaćena zamjenika, vikara, najamnika kojemu ovce nisu pripadale, preinačujući tako Božju riječ (Iv 10,12$).{ }^{27}$

U Nizozemskoj je bilo od 30 do 50 \% zastupnika koji su obavljali službu umjesto odsutnih kanonika, kurijalnih dužnosnika, sveučilišnih profesora.

Istodobno kada je pročitana Papina bula o reformi Crkve na 9. zasjedanju V. lateranskoga sabora 1514. godine poslano je i dopuštenje nadbiskupu Magdeburga i Mainza Albrechtu da uz naknadu od 10000 dukata kumulira spomenute biskupije. Za financiranje mu se prepušta polovica Petrova novca skupljena prodajom oprosta.

Kolika je bila zloupotreba kumuliranja biskupija i nadarbina pokazuje nam primjer kardinala Aleksandra Farnesea, nećaka pape Pavla III. On je još 1556. godine posjedovao 10 biskupija, 26 samostana i 133 nadarbine.

U Rimskoj kuriji vladala je neprestana oskudica novca zbog rastrošnoga i posvjetovnjačenoga života, opsežnih građevinskih radova i velikih ratnih troškova. Mnogi su dizali glas cijelo jedno stoljeće, ali su uvijek bili razočarani. Zbog fiskalne kurijalne politike osobito su pritužbe dolazile iz Njemačke. Martin Luther i ostali reformatori pridobili su mnoge ne zato što su se slagali s njihovim naukom, nego zato što su mislili da oni otvaraju put dugo željenim reformama.

U Njemačkoj je visoki kler isključivo biran iz plemstva. Biskupi i kanonici provodili su svjetovan život u lovu i zabavama. Za kelnskoga biskupa Hermana von Wieda kaže se da je za cijeloga života tri puta služio svetu misu. Od ukupnoga broja stanovništva klera je bilo 5 do $10 \%$. Svećenički proletarijat bio je siromašan, teološki

\footnotetext{
${ }^{26}$ E. ISERLOH, Martin Luther i izbijanje reformacije (1517. - 1525.), u: H. JEDIN (ur.), Velika povijest crkve, IV, Zagreb, 2004., 6.

${ }^{27}$ Isto, 7.
} 
neobrazovan i najvećim dijelom uopće nisu obdržavali celibat. U ženske samostane plemićke su obitelji prisilno slale svoje kćeri. ${ }^{28}$

\section{Politički, socijalni i psihološki uzroci}

\subsection{Proturimski stav}

Papa Inocent III. (1198. - 1216.) borio se protiv njemačkih careva koji su htjeli ujediniti južnu Italiju i Siciliju s carstvom. S jedne strane to bi dovelo do pada Crkvene Države, a s druge strane papa bi postao carev podanik, tj. carski biskup. On se borio protiv cezaropapizma, apsolutističke vladavine u kojoj je svjetovna i duhovna vlast u rukama cara, koja je bila tipična za bizantsku Crkvu i carsku Rusiju.

Nasljednici Inocenta III. borili su se i dalje protiv pretenzija njemačkih careva prema južnoj Italiji. Inocent IV. (1243. - 1254.) predao je južnu Italiju, Siciliju i Napulj kao papinsko leno Karlu Anžuvincu. Pape su se oslobodili moćnoga njemačkoga utjecaja, ali su zato potpali pod francuski utjecaj.

Proturimski stav posebno se osjećao u Njemačkoj zbog protunjemačke politike pape Ivana XXII. (1316. - 1334.), centralizma i financijske politike avinjonske kurije. Nakon što je Papa svrgnuo kralja Ljudevita Bavarskoga s prijestolja, u Njemačkoj su osjećali da »papinstvo postalo oruđe francuskih probitaka, a to su u Njemačkoj s gorčinom osjećali $\ll{ }^{29}$. Kralj Ljudevit na svom dvoru okupio je Papine neprijatelje. Među njima posebno ističemo pariške doktore Marsilija Padovanskoga, Ivana iz Janduna (1280. - 1328.) i franjevca Williama Ockhama. Marsilije i Ivan iz Janduma predali su kralju polemički spis Defensor pacis u kojem su nijekali hijerarhijsko ustrojstvo u Crkvi, božansko podrijetlo papinskoga primata, isticali su da kler nema prvenstvo nad laicima i da je najviši organ u Crkvi Sabor.

W. Ockham bio je osuđen kao heretik zato što je zastupao apsolutno siromaštvo. Krist i apostoli nisu imali nikakav posjed pa zato ni crkvene zajednice ne bi trebale imati. U strahu od progona bježi caru Ljudevitu Bavarskom kojem je rekao: »Ti mene brani mačem, a ja ću tebe perom. $\ll^{30} \mathrm{Za}$ Occama filozofija i vjera nisu bile kompatibilne discipline. Vjera je ta koja nas dovodi do istine, a ne razum. Odbija Crkvu kao posrednika između Boga i čovjeka.

Njemačke optužbe nalaze se u Gravamina nationis Germanicae. Luther se nadovezao na teške njemačke optužbe govoreći 1545 . godine da su Nijemci umorni od

\footnotetext{
${ }^{28}$ Usp. G. MARTINA, La Chiesa nell'età della Riforma, 83-84.

${ }^{29}$ A. FRANZEN, Pregled povijesti Crkve, Zagreb, 2004., 188.

${ }^{30}$ E. ISERLOH, Nominalizam. Pojam Crkve i ideja države u polemici 14. stoljeća. Laicistička država u Marsilija Padovanskog, 419.
} 
rimskih lijenčina i lupeža. Antirimski stav bio je u Njemačkoj tako snažan da je nuncij Girolamo Aleandro, boraveći u Wormsu 1521. godine, rekao da nema M. Luthera, došlo bi drugih stotinu Luthera. ${ }^{31}$

\subsection{OtPor CENTRALIZMU i APSOlUtNoJ VLADAVINi HabSBURgovaCA}

Za razliku od Engleske, Španjolske i Francuske gdje su kraljevi uspjeli potpuno podrediti pod svoju vlast plemstvo, u Njemačkoj je situacija bila potpuno drukčija. Knezovi su u Njemačkoj stekli regalna prava. U Njemačkoj centralna vlast praktički nije ni postojala.

Carevi iz kuće Habsburg nastojali su ojačati svoj autoritet. Po tradiciji su carevi bili branitelji Katoličke Crkve. Za očekivati je bilo da će njemački knezovi, carevi politički protivnici, zauzeti suprotna religiozna stajališta. ${ }^{32}$

Smrću cara Maksimiljana 1519. godine Lutherov slučaj otišao je u pozadinu. Papa Leon X. poslao je uputu kardinalu T. Kajetanu (1469. - 1534.) da svim silama spriječi izbor za cara Karla Španjolskoga iz kuće Habsburg. Kajetan je imao u ruci bulu izopćenja protiv Luthera, a sada je njegovu zaštitniku Fridrichu Mudrom trebao ponuditi carsku krunu. Papa je bio za izbor francuskoga kralja, a ako se to ne bi moglo ostvariti, onda bi sam Fridrich trebao preuzeti carsku krunu. Brinući se za Crkvenu Državu (strah od Habsburgovaca) i za obitelj Medici, Papa je pustio da proces protiv Luthera miruje cijelu godinu. Lutherov pokret mogao je pustiti korijenje.

\subsection{EKONOMSKO-SOCIJALNI UZROCI}

Otkriće Amerike posebno je pogodilo dva društvena sloja: seljake i srednjovjekovne vitezove. Vitezovi su izgubili svoj prijašnji društveni status bilo zbog promjena $\mathrm{u}$ načinu ratovanja bilo zbog porasta trgovine koja je umanjila vrijednost zemljišnih posjeda. U podjelama i vjerskim sukobima katolika i protestanata oni su vidjeli dobru prigodu dočepati se crkvene imovine. Njih nije vodio religiozni žar, nego stjecanje materijalne koristi.

Kao što su plemići mislili da će reformacija ispuniti njihova očekivanja, tako je i narod mislio da će reformacija ispuniti njihove socijalno-političke želje. Kratki i razumljivi letci donijeli su Lutheru veliku popularnost. Seljak je mogao čitati Bibliju na njemačkom jeziku. Mnogo toga što je bilo razumljivo samo po sebi počelo se dovoditi u pitanje.

\footnotetext{
${ }^{31}$ Usp. G. MARTINA, La Chiesa nell'età della Riforma, 86.

${ }^{32}$ Usp. isto, 86-87.
} 
Kod seljaka se u 16. stoljeću razvila nova svijest koja je tražila odgovarajuće mjesto u društvu. Vođe u seljačkom ratu bili su dobrostojeći i ugledni seljaci. U gradovima su se socijalno niži slojevi podigli protiv vladajućega građanstva. Sav siromašni obični puk digao je glas za svoj socijalno-politički položaj. U seljačkom ratu bili su izmiješani i seljaci i građani. Prije toga rata dolazilo je do lokalnih seljačkih buna koje su bile ugušene i nisu donijele nikakvih plodova.

Seljački ustanak počeo je 1524. godine pobudom seljaka u južnom Schwarzwaldu. Seljak i iskusni ratnik Hans Müller našao je saveznike u Waldshuttu. Pokret se proširio na Švapsku, Elsass, Franačku, Thüringen, Sasku, Tirol i Karantaniju.

Seljaci su izišli sa spisom Dvanaest temeljnih načela svakog seljaštva. Zwinglijevski propovjednik Christoph Schappeler prikazao je zahtjeve seljaka kao evanđeoske. U člancima se tražilo:

- slobodan izbor župnika i čista propovijed

- upotreba velike desetine za plaćanje župnika

- dokidanje kmetstva jer je Isus spasio sve ljude, te oni zato moraju biti slobodni

- ukinuće privilegija za lov i ribolov

- dokidanje male desetine.

Novina u toj pobuni jest da su zahtjevi izvedeni iz evanđelja. U početku su seljaci bili spremni na pregovore. Stapanje socijalno-ekonomskih zahtjeva s religioznim često je vodilo primjeni sile, pljački zamaka i samostana. Pobuna nije imala čvrstoga vodstva, logistiku i zato je sve izraslo u opću pljačku.

Seljaci su oči uprli u Luthera. On je napisao spis: »Upozorenje na mir u odnosu na dvanaest načela seljaštva u Švapskoj.« Luther piše: »( ... pustite na miru kršćansko ime i ne pravite od njega pokrivač sramote za vaše nestrpljivo, nemiroljubivo, nekršćansko ponašanje. ${ }^{33}$ Luther je opominjao gospodu da prestanu $\gg$ mrcvariti i guliti « seljake. »Nisu seljaci oni koji vam se suprotstavljaju. Sam Bog vam se suprotstavlja, pogođen vašim divljanjem.«

U drugom spisu Protiv razbojničkih i ubilačkih seljačkih horda Luther je vidio đavla na djelu i zato su knezovi trebali poduzeti bespoštedne korake.

$\gg$ U očima Božjim i carskim svaki ustanik je takav da onaj koji ga uhvati i zadavi, čini dobro. Jer za javnoga ustanika svaki je čovjek oboje: vrhovni sudac i izvršitelj kazne (...). Zato treba bacati, daviti, bosti, tajno i javno, tko god može, i sjetiti se da ništa ne može biti otrovnije, štetnije, đavolskije od buntov-

${ }^{33}$ E. ISERLOH, Borba oko poimanja slobode čovjeka kršćanina, u: H. JEDIN (ur.), Velika povijest Crkve, IV, Zagreb, 2004., 114. 
na čovjeka. To je isto kao kad moraš umlatiti bijesnog psa. Ako ti ne umlatiš, umlatit će on tebe i zajedno s tobom jednu veliku zemlju.

Zato, draga gospodo, oslobodite, spasite, pomozite. Smilujte se siromasima. Ubodi, udari, zadavi, tko samo može. Ako pri tom umreš, blago tebi, jednom blaženijom smrću ne bi nikada mogao umrijeti. Jer umireš u poslušnosti prema Božjoj riječi i Božjem nalogu (Rim 13) o i službi ljubavi spašavajući tvoga bližnjega iz đavolskih spona. $\ll^{34}$

Knezovi su bili bespoštedni i okrutni. Ubijeno je oko 100000 seljaka. Oni koji nisu pali u boju ubijeni su glavosjekom, nabijanjem na kolac, spaljivanjem ili osljepljivanjem. Svi ugovori u korist seljaka bili su poništeni. Seljaci su smatrali da je Luther odgovoran za počinjene okrutnosti. On je u jednoj zdravici 1533. godine rekao:

$\gg$ Propovjednici su najveći ubojice. Oni, naime, upozoruju poglavarstva da odlučno vrši svoju službu i kazni štetočine. Ja sam u ustanku potukao sve seljake; sva njihova krv na mome je vratu. Ali ja to prebacujem na našega Gospodina Boga, on mi je naredio da tako govorim $(. ..) . \ll 35$

Lutheru su osobito uzeli za zlo što se u takvim trenutcima, punim nevolje, dana 13. lipnja 1525. godine oženio cistercitskom redovnicom Katarinom Bora. Seljačkim ratom reformacija je prestala biti pučkim pokretom, a Luther je izgubio popularnost koju je do tada imao.

\subsection{PsihološKa Nestabilnost 15. STOLJEĆa}

U 15. st. kroz život odjekuje poklik memento mori. Propovijedanje o smrti bilo je uvijek prisutno. S pojavom prosjačkih redova i njihovim propovijedanjem i prikazivanjem smrti u drvorezu stvara se pučka, primitivna slika o smrti. U smrti je naglašena samo jedna crta: pojam prolaznosti. Zato su se koristili trima temama:

1. Gdje ostadoste svi vi koji ste nekoć ispunjavali svijet svojom veličajnošću?

2. Jezovit primjer raspadanja svega onoga što je sačinjavalo ljudsku ljepotu.

3. Smrt koja čupa i odvodi ljude iz svoga zvanja, iz svake dobi života.

Još u 16 st. nadgrobni su spomenici prikazivali gole lešine, istrunule ili smežurane, zgrčenih nogu i ruku i razjapljenih usta s crvima u utrobi. Žestoko gađenje od zemaljskoga raspadanja govori nam o materijalističkom duhu koji se ne može osloboditi misli o tijelu. Smrt je prikazivana kao apokaliptički jahač, kao kostur s kosom ili

\footnotetext{
${ }^{34}$ Isto.

${ }^{35}$ Isto, 115.
} 
strjelicom i lukom ili kao megera sa šišmišovim krilima. Najpoznatiji mrtvački ples nalazio se na arkadama groblja des Innocents u Parizu. ${ }^{36}$

Petnaesto stoljeće, jesen srednjega vijeka, zbog političke i socijalne nesigurnosti bilo je prožeto tjeskobom, nesigurnošću, strahom. Religioznost je znala poprimati i patološke oznake. Crna kuga iz 1348. godine opustošila je Europu. Strah od demona bio je općeprisutan. Posebno se očitovao u progonu vještica. Samo u jednoj godini u švicarskom kantonu Vallese spaljeno je 200 vještica. ${ }^{37}$

Dominikanci Heinrich Krämer i Jakob Sprenger uspjeli su postići od Inocenta VIII. godine 1484. bulu pod nazivom Summis desiderantes affectibus. U buli se polazi od pretpostavke da je mnogo osoba imalo spolni odnos s demonima. Godine 1487. dvojica spomenutih inkvizitora objavili su traktat Malleus Maleficarum u kojem sustavno objašnjavaju proces protiv vještica. Isusovac Martino Del Rio 1599. godine objavio je djelo pod nazivom Disquisitionum magicarum libri seks.

Duh vremena osobito se očitovao u umjetnosti. Peter Bruegel stariji naslikao je Trijunf smrti, Matthias Grünewald i Lukas Cranac prikazivali su napastovanje, Albrecht Dürer Konjanika, Smrt, Đavla.

U to vrijeme nastaje i apokaliptička literatura koja najavljuje kraj svijeta. Knjižica Onus Ecclesiae, tiskana 1524. godine, skupila je proročanstva Joakima da Fiore, Brigite Švedske, Vinka Fererskog. Duh toga vremena upio je i sam Martin Luther.

\section{Historiografija i teologija Martina Luthera}

\subsection{LUTHEROVA OSOBA U KATOLIČKOJ POLEMICI}

Od Wormskoga edikta Luther je već oslikavan kao »sin propasti «, »sijač zabluda «, »demon u ljudskom tijelu «, čovjek koji je »djelomično luđak, a djelomično opsjednut kakvim zlim duhom $\ll$, » vrhunski heretik i pobunjenik $\ll{ }^{38}$ To je bila uobičajena terminologija upotrebljavana za heretike. Djelo koje je najviše utjecalo da se kroz četiri stoljeća stvori negativna slika o Lutheru bilo je Commentaria de actis et scriptis Martini Lutheri (1549.) breslauskoga kanonika Johanesa Cochläusa. Različita tumačenja nisu točna. Druga pripadaju polemički nasilnim knjigama toga vremena. One nisu bile lišene kleveta, najsramotnijega opisivanja intimnoga, posebno seksualnoga života; odnos s đavlom; iznenadna smrt poslije obilne večere. Johanes Pistorius, liječnik i

\footnotetext{
${ }^{36}$ Usp. J. HUIZINGA, Jesen srednjega vijeka, 127-139.

${ }^{37}$ Usp. G. MARTINA, La Chiesa nell'età della Riforma, 84.

${ }^{38}$ B. LOHSE, Martin Luther, 143-168. Lohse donosi sliku o Lutheru od razdoblja protestantske ortodoksije, pijetizma, prosvjetiteljstva, njemačkih klasika do početaka znanstvenoga bavljenja Lutherom. Isto tako donosi i novije katoličke slike o Lutheru.
} 
obraćenik na katoličanstvo s luteranizma i kalvinizma, dodao je Cochleusovoj knjizi Anatomia Lutheri (1595. - 1598.). Autor je htio pokazati da je Luthera opsjelo sedam zlih duhova. U spisu se ne istražuje Lutherov život, nego njegova djela. Pistorius je čitao Lutherova djela tri puta, točno ih citirajući, ali birajući riječi i izraze koji ga moralno kvalificiraju u negativnom smislu. Prvo djelo prikazuje konkretno Lutherovo ponašanje, a drugo, utemeljeno na spisima, dalo je sliku reformatora:

- primjer poroka bludnosti, pijančevanja, proždrljivosti, licemjerja

- primjer oholosti, lažljivca, širitelja zabluda

- odgovoran za seljački rat.

Ta se slika, prema rezultatima istraživanja Adolfa Herta (Das katholische Lutherbild im Bann der Lutherkommentare des Cochläus), zadržala do tridesetih godina 20-og stoljeća. Takva slika ponavljana je također kod svetaca: sv. Roberta Bellarmina, sv. Lovre Brindiskoga, sv. Alfonsa M. de'Liguoria; u katoličkim priručnicima i enciklopedijskim člancima.

Heinrich Suso Denifle (1844. - 1905.), zamjenik vatikanskoga arhivara, reagirao je na pretjerano protestantsko uzdizanje Luthera. Protestanti su u Austriji širili klevete protiv Katoličke Crkve (djelo: Los von Luther, zurück zur Kirche). A. M. Weiss $\mathrm{u}$ djelu Luther und Luthertum in der ersten Entwicklung iznosi moralno-religioznu evoluciju mladoga redovnika Luthera, njegov život u nasilnim strastima i teološki razvoj koji je slijedio, odnos njegove teološke misli sa srednjovjekovnom dekadentnom skolastikom. Moralni Lutherov lik prikazan je bez pozitivnoga aspekta. Strasti koje su obuzimale Luthera (bludnost, bijes, mržnja) bacale su ga u očaj. On ih nije mogao pobijediti djelima pokore. Na polupelagijanski način nije mogao postići spasenje. Uvjeren da je požuda nepobjediva, iznašao je termin fede-fiduciale te negirao slobodnu volju. To objašnjenje nisu prihvatili ni katolici, a ni Hartmann Grisar (1845. - 1932.), koji je objavio spis Luther u tri sveska (Freiburg 1911. - 1912.). Sam je priznao da je ostao čist povjesničar, dakle parcijalan, u biti bez volje da ga razumije. Odstranio je mnoge legende, ali je duh i dalje neprijateljski, ponavljajući optužbe o Lutherovoj bolesti (sifilis) i moralnosti (u Wartburgu). U biografiji Martin Luther. Leben und sein Werk (1926.) ispustio je različite tvrdnje o Lutherovoj moralnosti, ali je u bitnim crtama Lutherov lik ostao isti. Objašnjenje krize i reformacije nije više promatrano u Lutherovoj amoralnosti, nego u psihološkom stanju, nažalost patološkom.

\subsection{Protestantsko tumaČenje lika i djela Martina Luthera}

Prve prosudbe o reformaciji potječu od Lutherovih prijatelja i učenika. U biblijsko-religioznom rječniku Luther je prikazan kao sanctus Domini, » prorok Jeremija «, »apo- 
kaliptički anđeo $\ll$ koji nosi »vječno Evanđelje $\ll$, $\gg$ njemački Mojsije «, $\gg$ duhovni osloboditelj «. Walter Kasper kaže da »ima toliko slika o Lutheru koliko ima knjiga o Lutheru $\ll{ }^{39}$ Zbog tumačenja Novoga zavjeta Luther je postavljen pokraj svetih pisaca biblijskih knjiga. Lutherova nauka promatrana je kao nezabludiva. U takvom mentalitetu kreirana je luteranska ortodoksija. U slavljenu 100 godina od njegovih teza (od 1617. godine) nastavlja se s Lutherovom proslavom umećući njegovu doktrinu u povijest spasenja.

Slabljenje ortodoksije vidi se u djelu Ludwiga von Seckendorfa (1626. - 1692.) Commentarius historicus et apologeticus de lutheranismo et reformatione (1688. - 1692.). Seckendorf, a s njim i pijetisti, zadržao se na prvih sedam godina reforme. U spisu se nalazi umjerena kritika. Knjiga završava molitvom za jedinstvo Crkve.

Pravi pijetizam započinje s Filipom Jacobom Spenerom (1635. - 1705.). Tražeći posredovanje između dviju strana, bio je udaljen od radikalizma. Naglasak nije stavljen na istinitost luteranskoga nauka, nego na usavršavanju vjere koja djeluje i pokazuje se u molitvi, u ljubavi prema Bogu i čovjeku. Pijetizam je konkretiziranje vjere u djelima. Lutherova osoba kritički je promatrana u ljudskim aspektima.

\subsection{Promjena mišljenja u tumačenju Martina Luthera}

Volja da se razumije Luther sazrijevala je polagano, osobito pod nacističkim režimom, kada su se konfesije počele približavati. U djelu Adolfa Herta Das katholische Lutherbild in Bann der Lutherkommentare des Cochläus (1943.) duh se promijenio. Započelo se s jednim novim razdobljem u katoličkoj historiografiji započevši od Josepha Lortza Die Reformation in Deutschland (Freiburg, 1939.). On vidi Luthera kao autentičnoga redovnika koji toliko duboko osjeća veličinu Božjega djela u čovjeku da nestaje čovjekov udio u procesu spasenja. On se zato borio protiv uvjerenja da se dobrim djelima možemo posvetiti. Luther je bio protiv jednoga katoličanstva koje više nije bilo katoličanstvo. Ne manjkaju optužbe za subjektivizam; za egzegezu koju je stavio ispred svega; za vlastito iskustvo iz kojega je promatrao sve: čovjeka, svijet, Boga; da je odbio crkveno učiteljstvo i da je podijelio Crkvu.

H. Jedin, iako potaknut ekumenskim duhom, vidi velike poteškoće u približavanju na dogmatskom području. Definicije i osude Tridentskoga koncila ne mogu se lagano nadići jer su razmatrale luteransku doktrinu. Unatoč dobroj volji da se ne gleda rječnik, moralni defekti, apsolutne Lutherove tvrdnje, pojedine fundamentalne postavke takve su da se moraju kritički promatrati.

U novijem tumačenju M. Luthera vrijedan doprinos dao je Otto Herman Pesch. On promatra Lutherovu teologiju u povezanosti s kasnom srednjovjekovnom teo-

${ }^{39}$ W. KASPER, Martin Luther. Ekumenska perspektiva, Zagreb, 2017., 9. 
logijom. Luthera naziva kasnim srednjovjekovnim teologom s originalnim idejama koje je tražio kod najvećih svjedoka vjere, Pavla i Augustina. ${ }^{40}$

\subsection{Teologija Martina Luthera}

O nutarnjem Lutherovu razvoju do 1511. godine znamo veoma malo. Znamo da se susreo s okamizmom u Erfurtu. Na povratku u Erfurt doživljava nesreću u olujnom nevremenu. Pogođen munjom, zavjetovao se sv. Ani: »Pomozi, sv. Ano, postat ću redovnik. ${ }^{41}$ Je li ta odluka iznenadna ili je već nutarnje pripremljena? Stupa u red augustinijanaca. Luther osjeća strasti, mržnju, duhovnu žalost, nesigurnost, razočaranost, često se ispovijeda. Najvažnija točka u tom razdoblju jest uvjerenje mladoga monaha da može svojim silama postići nebo. Čita mističara Taulera. Lutherov ispovjednik Johannes Staupitz pomagao mu je postići nutarnju slobodu. On mu je govorio da gleda rane Raspetoga koji je za nas umro i prinio sebe kao zadovoljštinu. ${ }^{42}$ Lutheru, koji je osjećao Božju srdžbu, govorio je: »Čovječe, Bog se ne ljuti na tebe. $\ll{ }^{43}$

Na događaje koji će uslijediti utjecali su:

- diskusija u samostanu o spasenju i milosti

- odgovornost kao doktora teologije

- dar u naviještanju Božje riječi koji mu je dao naslov »Wittenberški propovjednik «. ${ }^{44}$

Dana 31. listopada 1517. godine Martin Luther objavio je svojih 95 teza o oprostima. Teze su bile reakcija na propovijedanje oprosta dominikanca Ivana Tezela. Pod oprostom se podrazumijeva otpuštanje pokore ili vremenite kazne za grijehe. Zbog gomilanja oprosta u kasnom srednjem vijeku, kao i fiskalnoga iskorištavanja bilo Rimske kurije bilo velikaša došlo je do izrugivanja oprosta. Komercijalizirani oprosti stvarali su kod vjernika lažnu sigurnost i odvraćali su ih od prave pokore, tj. obraćenja i odreknuća od grijeha. ${ }^{45}$

${ }^{40}$ Usp. O. H. PESCH, Martin Lutero. Introduzione storica e teologica, Brescia, 2007., 18.

${ }^{41}$ E. ISERLOH, Uzroci reformacije, u: H. JEDIN (ur.), Velika povijest Crkve, IV, Zagreb, 2004., 15.

${ }^{42}$ A. FRANZEN, Pregled povijesti Crkve, 218.

${ }^{43}$ R. H. BAINTON, Na tome stojim. Život Martina Luthera, Zagreb, 2002., 49.

${ }^{44}$ B. LOHSE, Martin Luther, 36.

${ }^{45}$ Usp. G. GRBEŠIĆ, O nekim aspektima teološke misli Martina Luthera prigodom 500. obljetnice početka protestantske reformacije, u: Vjesnik Đakovačko-osječke nadbiskupije i Srijemske biskupije 145(2017.)11, 33-39., ovdje 33. 
Od 1532. godine Luther u predavanjima i zdravicama govori o jednoj spoznaji, doživljaju u tornju ${ }^{46}$ koji mu je omogućio sasvim novo shvaćanje evanđelja. To je za njega bio prijelaz iz paklenoga straha prema radosti, životu i spasenju. Riječ je o shvaćanju Božje pravednosti. Poslije doživljaja u tornju samostana u Wittenbergu shvatio je da se Božja pravednost sastoji u tome da smo po Kristu opravdani i otkupljeni.

»Ovo Lutherovo 'prosvjetljenje' duboko je katoličko. Kao svećenik Luther je u misi molio sljedeće molitve: 'Mi koji se ne uzdajemo u svoju pravednost' (misa Justus ut palma), '... jer se ne pouzdajemo ni u jedno svoje djelo' (Dominica in Seksagesima), 'mi koji se uzdajemo u tvoju snagu.' Ove molitve veličaju Božjoj pravednosti i snagu, a ne ljudska djela. Očito da Luther nije prepoznao sadržaj ovih molitava. « ${ }^{47}$

Ovdje ne možemo iznijeti svu teologiju M. Luthera, nego onu najvažniju iz triju programatskih spisa iz 1520 godine:

1. Kršćanskom plemstvu njemačke nacije o poboljšanju kršćanskog staleža

2. O babilonskom sužanjstvu Crkve

3. O slobodi kršćanina.

U Lutherovoj teologiji oblikovala su se tri principa, poznata kao tri sola. Opravdanje samo po milosti (sola gratia) i vjeri (sola fide), a Sveto pismo jedini je teološki temelj (sola scriptura). Luther, misleći da tumači misao sv. Augustina, poistovjetio je istočni grijeh s požudom koja je trajno u nama. Istočni grijeh potpuno je iskvario ljudsku narav. Sakrament krštenja ne briše istočni grijeh, a vjernik je istovremeno i grješnik i opravdan. Opravdanje je samo u nadi (in spe), ali u stvarnosti (in re) je grješnik. Za Luthera je opravdanje samo izvanjsko. Tridentski sabor jasno će potvrditi da je to opravdanje ontološko. (DZ 1532, 1535, 1546)

U potpunosti pokvaren čovjek ne može činiti dobra djela. Ona su beskorisna jer proizlaze iz izopačene naravi. Bog sve čini u čovjeku. Jakovljevu poslanicu Luther je nazvao slamnatom poslanicom zato što je rušila njegov koncept $\gg$ samo vjera $\ll($ sola fide). »Tako i vjera: ako nema djela mrtva je u sebi.« (Jak 2, 17)

U svom spisu O Slobodnoj volji Erazmo Roterdamski prodro je u bit Lutherova nauka koji niječe čovjekovu slobodnu volju. Za razliku od drugih koji su u središte rasprave stavljali papinstvo, čistilište ili oproste, Luther odaje priznanje Erazmu što je uočio jednu od najvažnijih njegovih postavki. ${ }^{48}$

\footnotetext{
${ }^{46}$ E. ISERLOH, Uzroci reformacije, 29.

${ }^{47}$ Usp. isto, 33-39.

${ }^{48}$ Usp. M. VENARD, Erasmus gegen Luther, u: J. M. MAYEUR, C. i L. PIETRI, A. VAUCHES, M.VENARD (ur.), Die Geschichte des Christentums, VII, Wien, 1995., 860.
} 
U spisu O babilonskom sužanjstvu Crkve Luther niječe sedam sakramenata i žrtveni karakter mise. U kritici euharistije on vidi tri sužanjstva: izostavljanje kaleža za laike, nauk o transsupstacijaciji u kojem vidi ljudsku izmišljotinu, o misi kao žrtvi. ${ }^{49}$ Luther dopušta sveopće svećenstvo, ali ne i sakramentalno. Po nauci Katoličke Crkve transformacija kruha i vina u svetoj misi naziva se transsupstancijacija (DZ, 1642). Luther naučava konsupstancijaciju. Krist je prisutan u euharistiji, koegzistira s kruhom i vinom, ali kruh i vino ne postaju Tijelo i Krv Kristova. Pozivajući se na Poslanicu Hebrejima, koja kaže da se Krist jednom zauvijek prinio Ocu nebeskom, naziva svećenike $\gg$ Baalove popine $\ll^{50}$ koji svojim žrtvovanjem ponovno razapinju Isusa. Za Luthera misa nije žrtva, nego oporuka.

\section{Zaključak}

Prema protestantskim autorima reformatori nisu htjeli odvajanje od Crkve, nego njezinu obnovu. U stvarnosti oni su htjeli promijeniti njezin nauk s obzirom na opravdanje, papinski primat, žrtveni karakter mise, istočni grijeh, slobodnu volju, sakramente. Dakle nije riječ o moralnoj ili administrativnoj obnovi, nego o doktrinarnim promjenama koje su morale dovesti do podjele.

Uzroke reformacije ne smijemo tražiti u oprostima, nego u događajima koji su joj prethodili. Avinjonskim sužanjstvom i velikim zapadnim raskolom pape su izgubili svoj univerzalni značaj. Zbog oslabljenoga papinstva koncilijaristička teorija ponovno je zaživjela, a dekadentna skolastika pogodovala je razvoju nominalizma koji u središte misli nije stavljao univerzalno i objektivno, nego individualno. Teološka pitanja koja je Luther razvio već su bila prisutna u 14. i 15. stoljeću. Svojom osobnošću, osobnim iskustvom, ljutitim temperamentom, propovjedničkim darom tim pitanjima dao je sasvim novu težinu koja je od tako tražene reforme Crkve dovela do reformacije.

\footnotetext{
${ }^{49}$ Usp. B. LOHSE, Martin Luther, 100.

${ }^{50}$ E. ISERLOH, Uzroci reformacije, 69.
} 


\section{THE CAUSES OF THE PROTESTANT REFORMATION}

\section{Grgo GRBEŠI $\mathbf{C ́}^{*}$}

Summary: The causes of the Protestant Reformation are divided into five groups: historical, theological, spiritual-religious, political, social and psychological, and the theology of Martin Luther. Until the twentieth century, the traditional opinion was that the root cause of the Reformation should be sought in the many abuses in the Church. Today, both Catholic and Protestant authors look at the problem much broader and deeper and embrace the theological thought, especially the nominalism which significantly influenced Luther himself. In a combination of different circumstances - political, social, psychological - Luther's personality also dominated. As a professor of Bible courses, he was particularly interested in the study of the Epistles to the Romans and Galatians. The question of indulgences triggered a large flood that could not be stopped. Indulgences were only the last straw but not the cause of the Protestant Reformation.

Keywords: Martin Luther, Reformation, justification, original sin, free will, scholasticism, nominalism, humanism.

* Asst. Prof. Grgo Grbešić, Ph. D., Catholic Faculty of Theology in Đakovo, J. J. Strossmayer University of Osijek, P. Preradovića 17, 31400 Đakovo, Croatia, grgo.grbesic@gmail.com 